\title{
Potential Solution for Plastic Degradation-- Genetical Modification
}

\author{
BoYi Xia
}

SWU, ChongQing, 400715, China,

1826227035@qq.com

\begin{abstract}
Plastic, Invented in 1909. More accurately, phenol-formaldehyde resin, first kind of plastic was invented in 1909. Plastic, as a shapable and flexible material, has entered nearly everywhere of our lives. Plastics always take up in an irreplaceable role without any doubts, whereas, with the using of plastics, some irreversible damages have crushed the earth and left their footprints. Nowadays, in order to reduce or even eliminate these awful outcomes, plastic degradation, in other words, a way to reverse these damages, should be put more concentration on. This work tries to provide a worth-considering way which overlap the plastic degradation and genetic engineering to handle this problem. In additional, this work also discussed the perniciousness of plastic products and ethical problems in this article.
\end{abstract}

Keywords: plastic degradation, genetic engineering, micro-organism

\section{INTRODUCTIONS}

\subsection{The perniciousness of plastic products}

Plastic, as an essential material, its production refers to many industries and its output constantly increasing. It has been detailed that the world's manufactured plastic generation will be around 1800 million tons in 2050 and around 12,000 million metric tons of plastic squander will be within the environment by that year , and It has been assessed that nearly 6.4 million tons of squander is presented into marine situations every year. As approximately $90 \%$ of the products made with plastic are used once and then discarded[1]. the production of plastics will affect the environment, including the organisms, very directly. Nowadays, we sort plastic pollution into three types. Macro-plastic, Macro-plastic and Nano-plastic. Each of them will damages the environment in different ways.

For Macro-plastic, many aquatic animals may become entrapped and entangled within plastic debris since, unlike people, they are unable to free themselves and some aquatic animals will mistakenly regard the plastic bags as their main food resource-'jelly fish' and take in this jelly fish-like plastic bags[2].Consequently, these animals will be choked or just cannot digest these plastic materials and die of choked or starving. Turtles, the representative of this situation. A quantitative analysis linking turtle mortality with plastic debris intake revealed the damage caused to turtles. The study tested the relationship between the amount of plastic intake by turtles and the probability of death, and used animals whose deaths of known causes unrelated to plastic intake were used as a statistical control group. This study uses two data sets; one is based on the autopsy of 246 turtles, and the other uses 706 records extracted from the national stranded database. Compared with animals that die for unknown reasons or directly from plastic intake, fewer plastics die in the intestines of animals for known causes unrelated to plastic intake. The study found that once an animal has 14 plastics in its intestines, its death probability is 50\%. The researchers' results provide a key link between recent estimates of plastic intake and the impact of this environmental threat on the population. 


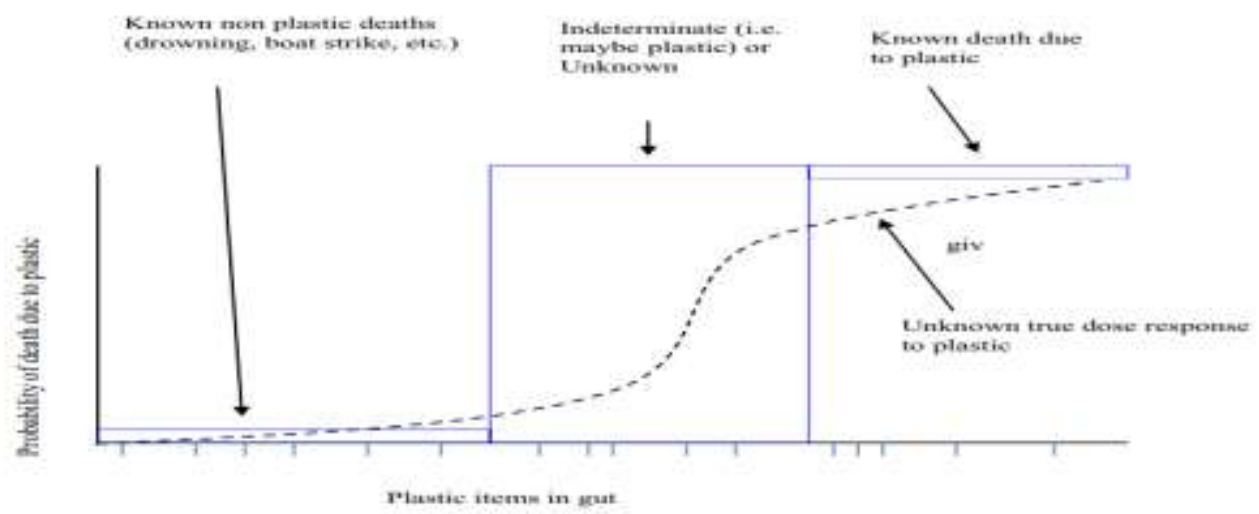

Figure 1. Probability of death due to plastic

Conceptual system for assessing the likelihood of passing due to plastic flotsam and jetsam ingestion. Blue lines along the $\mathrm{x}$ pivot appear perceptions of turtles with plastic in their intestine. Blue boxes with names appear the hypothesized area along the $\mathrm{x}$ and $\mathrm{y}$ pivot of the creatures with different destinies, in the event that plastic causes deadly impacts. dark specked line appears a hypothesized, but in secret, relationship between the sum of plastic within the intestine and the probability of mortality due to plastic for an person turtle[3/4].

-1.2 For Microplastics, any antagonistic impacts would be anticipated to be due to their physical instead of chemical nearness as the potential for poisonous quality from following chemicals is thought to be negligible.

-1.3 For nano-plastics, nano-plastics were found that they can affect some aquatic animals behaviors and also have some unfavorable impacts would be anticipated to be due to their physical rather than chemical closeness as the potential for hurtfulness from taking after chemicals is thought to be unimportant [5].

\section{SOME CURRENT WAYS TO DEAL WITH PLASTIC POLLUTION}

\subsection{Landfill Treatment}
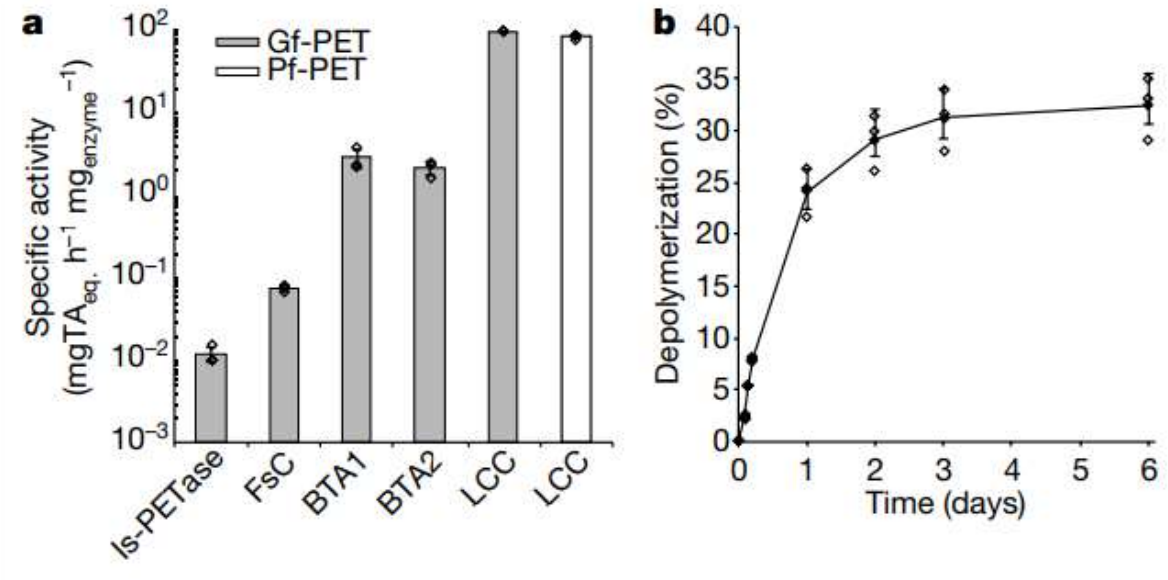

Some plastics are processed to recycle. However, the ability to recycle is limited. Therefore, landfill treatment will always be the second choice.

\subsection{Combusting Treatment}

Combusting is also a normal way to handle garbage and most of its is plastic. However, this process will release many poison gas and substances.

\section{LCC FOR THE DEGRADATION OF PETROLEUM-BASED POLYMERS}

With the research on plastic degradation keep going on, increasing number of materials have been found which are efficient about digesting the plastic wastes. Among the catalase been found, LCC (leaf-branch compost cutinase) have been proved to be very efficient. For LCC, research used a commercially available amorphous PET to compare the activity of several enzymes reported previously to hydrolase PET in their optimal conditions. LCC outperformed all other enzymes tested [6]. In additional, there are also some advantages about LCC when conducting a genetic engineering, The sequence of LCC was identified and was deposited into NCBI. (GenBank: HQ704839.1)

Figure 2. LCC outperformed all other evaluated PET hydrolases during PETdepolymerization assays. a, 
Comparison of the specific hydrolysis activity towards amorphous Gf-PET by: Is-PETase or FsC in 50 $\mathrm{mM}$ glycine $\mathrm{NaOH}$ buffer, $\mathrm{pH}$, at $40{ }^{\circ} \mathrm{C}$; BTAhydrolase 1 or BTA-hydrolase 2 (BTA1 and BTA2 respectively) in $1 \mathrm{M}$ potassium phosphate buffer, $\mathrm{pH} 8$, at $65{ }^{\circ} \mathrm{C}$; and $\mathrm{LCC}$ in $100 \mathrm{mM}$ potassium phosphate buffer, $\mathrm{pH} 8$, at $65{ }^{\circ} \mathrm{C}$. The hydrolysis of Pf-PET by LCC in $100 \mathrm{mM}$ potassium phosphate buffer, $\mathrm{pH} 8$, at $65{ }^{\circ} \mathrm{C}$ is also shown. Equimolar amounts of purified proteins were used (6.9 nmolprotein gPET -1 and 2 gPET lbuffer -1$)$. Means \pm s.d. $(n=3)$ are shown. b, Detailed hydrolysis kinetics for Pf-PET depolymerization by LCC, as described in a. Each filled symbol represents the mean \pm s.d. $(n=3)$. [7]

\section{FUNGAL POTENTIAL FOR THE DEGRADATION OF PETROLEUM-BASED POLYMERS}

This work must consider microorganisms, because they can multiply quickly and are suitable for genetic engineering goals, because rapid reproduction means that they can digest plastic pollution very effectively. These days, researchers have found a fungus called filamentous creatures. Filamentous parasites play a vital role in the degradation and mineralization of various natural toxins by catalyzing important chemical reactions. Fungi are heterotrophic organisms that eat by absorbing extracellular nutrients. They release digestive enzymes through extrahyphaal cell vomiting, decompose macromolecules and organic molecules into smaller organic compounds, reabsorb, and release $\mathrm{CO} 2$ and $\mathrm{H} 2 \mathrm{O}$ under aerobic conditions if the matrix is mineralized. Fungi have different unusual methods to neutralize various complex compounds, some of which are toxins and harmful substances. Fungi have various unique strategies to fight against many complex compounds. These strategies include powerful enzyme systems, adsorption capabilities and the production of natural biological surfactants to enable them to use polymers.

This enzymatic system is mediated by the cytochrome P450 family (CYP), CYP are a large family of enzymes and heme-containing monooxygenases (mainly) that are able to catalyze various enzymatic reactions.

Enzyme frameworks can catalyze a variety of reaction components, making them far-reachingly helpful to toxic decay, because their different components bind to their intracellular and extracellular enzyme frameworks. As an internal tool for detoxification, intracellular enzyme framework plays an important role in infectious adaptation.

Extracellular enzyme frameworks include hydrolytic frameworks that produce hydrolytic enzymes (which can cause polysaccharide corruption) and uncommon and non-specific oxidation frameworks contained in complex structural decomposition. Hydroxyllation can be regarded as a biotransformation method in the form of bioremediation, because it increases the solubility of toxins and thus reduces the potential for bioaccumulation. This oxidation framework can oxidize a wide range of substrates and can become an effective device for natural cleaning [7].

\section{SOME USEFUL WAY}

\section{(1)Heat shock transcription}

Plasmid is an important target of this method. In this method, the plasmid is used to carry the target gene, and the plasmid is transferred into the target bacteria, so that the target bacteria can carry the target gene. The plasmid is a small circular double stranded DNA, which can reduce its volume through super helix folding, so it is easy to pass through the small holes on the cell membrane. There are multiple cloning sites on the commercial plasmid, referred to as MCS. This region contains special sequences that can be recognized and cleaved by restriction enzymes. When the same restriction enzyme is used to cut the plasmid and DNA fragment, the researchers can insert the target DNA fragment into the polyclonal site. Then the related plasmids were introduced into bacteria by heat shock transformation [8].

\section{(2)CRISPR/Cas9-mediated genome editing}

CRISPR/Cas9 system is a fast, simple and usually very effective gene editing method. Cas9 protein comes from the type II CRISPR bacterial immune system and is becoming a powerful tool for building the genome in a variety of organisms. As an RNA-guided DNA incision enzyme, Cas9 can easily program by changing its guided RNA sequence to locate new locus, and its development as a tool makes sequence-specific gene editing easier. Cas9's nuclease inactivation forms further provide a multifunctional RNA-guided DNA targeting platform for regulating and imaging genomes and rewriting epigenetic states, all in sequence-specific ways[9].

\section{POSSIBLE TARGET FOR GENETIC ENGINEERING}

\section{(1)Fungus}

As the benefit of fungus as the receptor to digest plastic pollution has been revealed, at the same time, fungus has also been admitted that they are also good targets for genetic engineering as their way of reproducing, most of fungus reproduce by spores which means they can travel with winds in a far distance and aided by their speed of reproducing, they can easily participate in cleaning the plastic pollution globally.

(2)Halophilic bacteria 
As the plastic pollution in the ocean is extremely serious. However, most of the micro-organisms cannot live in the ocean due to the high concentration of the salt. Fortunately, Halophilic bacteria can tolerate such situation. In additional, this kind of bacterial has been proved to be a great receptor of genetic modification[10].

\section{ETHIC PROBLEMS OF GENETIC ENGINEERING}

(1) The growth of some fungus will absorb the water and nutrients in the soil, which will destroy the root tissue and lead to root rot, so it will do great harm to the forest. However, such species are also an important part of forest ecosystem. In a word, the advantages outweigh the disadvantages.

(2) Overspreading may interfere with other organisms as plastic, their potential food resources, has a huge amount and extensive spreads.

(3) We also should considerate about the possibility of gene contamination, as these modified genes may flows to other specials which will lead to a disaster.

(4) using CAS9 technology for generating geneedited animals involves a number of obstacles, which means the modified organisms may suffer from painful disease or even cannot survive.

\section{CONCLUSION}

It is undoubtedly great to witness the development of world. However, we must take a little stop and start to thinking, is this unsustainable developing truly what we want? We must aware the flaws and the potential damage it may bring to us. We must take a step to fix this situation up. Plastic problem is a good entry point. Many useful ways have been found out to deal with this problem but they are not enough. With the science developing at the same time, we must combine our newest knowledge with newest tech to handle this problem. Here comes the genetic modification as a way to help us to achieve this goal. In the future, we believe increasing numbers of solution to plastic pollution will be found and been applied to daily life which will be boon to our offsprings and their future.

\section{REFERENCES}

[1]. Sánchez C. Fungal potential for the degradation of petroleum-based polymers: An overview of macroand microplastics biodegradation. Biotechnol Adv. 2020 May-Jun;40:107501. doi: 10.1016/j.biotechadv.2019.107501. Epub 2019 Dec 20. PMID: 31870825.$)$

[2]. (Waring RH, Harris RM, Mitchell SC. Plastic contamination of the food chain: A threat to human health? Maturitas. 2018 Sep;115:64-68. doi: 10.1016/j.maturitas.2018.06.010. Epub 2018 Jun 20. PMID: 30049349. )

[3]. Wilcox C, Puckridge M, Schuyler QA, Townsend $\mathrm{K}$, Hardesty BD. A quantitative analysis linking sea turtle mortality and plastic debris ingestion. Sci Rep. $2018 \quad$ Sep 13;8(1):12536. doi: 10.1038/s41598-018-30038-z. PMID: 30213956; PMCID: PMC6137038.

[4]. Wilcox C, Puckridge M, Schuyler QA, Townsend $\mathrm{K}$, Hardesty BD. A quantitative analysis linking sea turtle mortality and plastic debris ingestion. Sci Rep. $2018 \quad$ Sep 13;8(1):12536. doi: 10.1038/s41598-018-30038-z. PMID: 30213956; PMCID: PMC6137038.

[5]. Sánchez C. Fungal potential for the degradation of petroleum-based polymers: An overview of macroand microplastics biodegradation. Biotechnol Adv. 2020 May-Jun;40:107501. doi: 10.1016/j.biotechadv.2019.107501. Epub 2019 Dec 20. PMID: 31870825.)

[6]. Tournier V, Topham CM, Gilles A, David B, Folgoas C, Moya-Leclair E, Kamionka E, Desrousseaux ML, Texier H, Gavalda S, Cot M, Guémard E, Dalibey M, Nomme J, Cioci G, Barbe S, Chateau M, André I, Duquesne S, Marty A. An engineered PET depolymerase to break down and recycle plastic bottles. Nature. 2020 Apr;580(7802):216-219. doi: 10.1038/s41586-0202149-4. Epub 2020 Apr 8. PMID: 32269349.

[7]. Tournier V, Topham CM, Gilles A, David B, Folgoas C, Moya-Leclair E, Kamionka E, Desrousseaux ML, Texier H, Gavalda S, Cot M, Guémard E, Dalibey M, Nomme J, Cioci G, Barbe S, Chateau M, André I, Duquesne S, Marty A. An engineered PET depolymerase to break down and recycle plastic bottles. Nature. 2020 Apr;580(7802):216-219. doi: 10.1038/s41586-0202149-4. Epub 2020 Apr 8. PMID: 32269349.

[8]. Goodson ML, Sarge KD. Heat-inducible DNA binding of purified heat shock transcription factor 1. J Biol Chem. 1995 Feb 10;270(6):2447-50. doi: 10.1074/jbc.270.6.2447. PMID: 7852305.

[9]. Wang H, La Russa M, Qi LS. CRISPR/Cas9 in Genome Editing and Beyond. Annu Rev Biochem. 2016 Jun 2;85:227-64. doi: 10.1146/annurevbiochem-060815-014607. Epub 2016 Apr 25. PMID: 27145843.

[10]. Afendra AS, Vargas C, Nieto JJ, Drainas C. Gene transfer and expression of recombinant proteins in moderately halophilic bacteria. Methods Mol Biol. 2004;267:209-23. doi: 10.1385/1-59259-7742:209. PMID: 15269426 . 